\title{
Fighting for Uyghur Rights
}

\section{Rebiya Kadeer}

I begin my brief story in the 1960s, when many Uyghur (also spelled "Uygur" and "Uighur") people, including myself, struggled against starvation. The already difficult lives of Uyghurs living in East Turkestan ${ }^{1}$ (also known as the Xinjiang Uyghur Autonomous Region [XUAR]) under Chinese government rule became much worse during the Cultural Revolution. Everything was rationed and controlled by the government and food was in very short supply. There was no private enterprise. Trying to find any way I could to alleviate the poverty we were suffering, I started to make and sell children's clothes. I also took in laundry to earn some money. From there, I began to travel to different cities (first within East Turkestan and later throughout China) buying fabrics and garments and selling them on the street. Of course, this was not allowed under the communist system, and many times the Chinese police confiscated all of my goods and charged me with "taking the road of the capitalists." Nor was it usual for a woman to travel in the region. I endured many hardships and indignities, but I was determined to care for my children and improve my life.

During the 1980s, as China began its economic reforms, I was able to set up a small store to do business in Urumchi, the capital of East Turkestan, and gradually started to prosper. I always tried to encourage the other Uyghur street sellers and merchants as well. In March 1987, I established the "Eighth of March" market (named in honor of International Women's Day), a covered marketplace that housed ninety-three stores and stands. In 1989, I built a seven-story apartment building, and a few years later I built the Rebiya Kadeer Department Store in downtown Urumchi. The Uyghur street vendors could come and sell their goods in my store. At some point in my struggle for economic independence, I became one of the ten richest people in China, for my business eventually grew into a multi-million dollar trading company.

Rebiya Kadeer is president of the International Uyghur Human Rights and Democracy Foundation (IUHRDF) and the Uyghur American Association, both based in Washington, DC. For more information about IUHRDF, contact info@iuhrdf.org. (Website is under construction.) This article was translated by Alim Seytoff, director of the Uyghur Human Rights Project at the Uyghur American Association (www.uyghuramerican.org), and edited by Miriam A. Young, an expert on human rights in the Asia region and former executive director of the Asia Pacific Center for Justice and Peace. 
During the 1990s, as Uyghur cities were growing, our region became the home of thousands of Han Chinese brought in by the government to settle in the XUAR. But the Uyghurs were not prospering, and I was especially concerned about the situation of Uyghur women. I traveled constantly for my business and observed everywhere how poor my people were, as well as the general lack of education and opportunities to improve their lives. Women were the hardest hit. I asked the National Women's Association for help to improve Uyghur women's lives, for my economic success gave me access to Chinese governmental bodies. But I got nowhere. I always helped out single families or donated money for schools, but it was not enough.

So, on 15 December 1997, along with thirty-five other Uyghur women, I established the "Thousand Mothers Movement." My goal was to promote women's education and increase their economic activities, thereby promoting and enabling their active involvement in civil society. Once women became successful, I thought, they could, in turn, help other women.

At the first public meeting, I was hoping that at least fifty women would show up. Instead, 2,000 women came! I told the women that day that we owed it to our children, we owed it to our land, and we owed it to ourselves, each one of us, to take on the task of empowering women. More than 1,000 women ultimately invested their money in the organization. We obtained official registration papers and a business license. For the inauguration day, the government sent its most prominent woman to cut the ribbon - Ms. Maynur Kasim, head of the XUAR Women's Association, director of the Regional Congress, and vice chairwoman of the National Women's Association.

Inexplicably, a mere two months later, Beijing shut down the movement and froze our bank account. We had no idea what kind of mistake we had made, but it was clear that Beijing did not approve of what we were doing: taking our own initiative to empower ourselves. There was nothing to do but for me to use my own money to pay back the women who had invested their funds in the project and the dream.

About the time that I was launching the Thousand Mothers Movement, others were looking for ways to resolve the moral crisis that the Uyghurs were facing throughout East Turkestan. In Ili region, people revived a Uyghur cultural event called mashrap, during which the actors/presenters preached to the people to quit drinking and taking drugs, and go to the mosques and help others. They attempted to revive the moral values through religion. But in early 1997, Beijing charged the organizers with conducting illegal religious activities and began to arrest both the organizers and the attendees. This led to the now infamous (for Uyghurs) "Ghulja massacre." 
On 5 February 1997, in Ghulja city in Ili, Uygurs held a peaceful demonstration to demand the release of those who had been detained for their involvement in the mashraps and to call for human rights, democracy, and religious freedom. In response, fully armed paramilitaries (wuzhuan jincha) were dispatched to crush the protest. They opened fire on the crowd, killed several hundred Uyghurs, and then arrested all of the protesters. The authorities claimed that no one had been killed.

After the Ghulja massacre, Beijing strictly monitored and controlled the activities of mosques and clergy all over East Turkestan. The most popular clergy were removed or arrested, and then replaced with others, who had been indoctrinated by the government. Minors were openly forbidden to go to mosques, and Uyghur high school and college students were suspended if they were caught observing their religion (praying). Those Uyghurs who organized underground religious schools were arrested. In 1998, for example, the government shut down sixty-five religious schools in the Hotan region and sixty-three in the Aksu region, all of which had been operating since 1990. The organizers were arrested. As a result of China's strict religious control and the destruction of their moral values, many Uyghurs fell into drug use and other destructive behavior. In Ili, more than 80 percent of those with HIV/AIDs are Uyghurs.

Normally, religion plays an important role in eradicating people's moral crises by helping them live in harmony with themselves and with each other. In short, religion teaches people the best way of life and offers moral support when they are depressed or unhappy. Without it, the young people could not find a way out of their problems. I felt that I had to speak out for the demoralized Uyghur people.

As stated earlier, my economic success had earned me access to certain government offices. Between 1987 and 1996, I received eighteen awards for paying my taxes on time and was a member of the XUAR Peoples Congress (1987-1992). Later on, I was made a member of China's Political Consultative Conference, a high honor for an ethnic minority. But in 1997, at the annual session of the National People's Congress, I spoke out about the Uyghurs' economic, educational, and cultural rights. Although I had raised these issues before, this was the first time I had done so nationally. I was rewarded by being stripped of all my official titles and medals, and forbidden to travel abroad. I then decided to raise the issue internationally.

On 11 August 1999, I decided to meet members of an American congressional delegation to explain my people's situation. But I was arrested on my way to the hotel. I was carrying a letter in which I made ten demands of Washington. For this act, I was sentenced to eight years in prison for reveal- 
ing so-called "state secrets." I spent six years of my sentence in prison. Beijing harassed my businesses after my arrest by suddenly cutting off the power, shutting down the water, adding taxes, and disrupting the normal business of the restaurants I owned as well as my relations with other business partners and banks. My business suffered huge economic losses.

Thanks to sustained international pressure, especially from human rights groups and the American government, Beijing released me for "medical reasons" and allowed me to come to this country. I arrived in Washington, DC, on 17 March 2005, and since then have been breathing the air of freedom. Just before my release, a Chinese foreign ministry official warned me: "If you engage in any activity that makes China look bad, and if you associate with Uyghur political activists, your children and your business will be finished in an unimaginable way." But from the day I landed in this democratic country, I have not stopped campaigning for the rights of the long-suffering Uyghur people. If it makes China look bad, I cannot help it.

The Chinese did not take long to make good on their threat. Just days after I testified before Congress for the first time and after giving an interview to a Norwegian media conference, 300 armed police raided my company in Urumchi. They confiscated every single official document, including contracts, tax papers, and other documents. The material filled fifteen bags. They arrested the director and secretary of the company a few days later, and my children were put under house arrest for two weeks.

In August 2005, the XUAR's party secretary held a press conference in Beijing in which he accused me of colluding with foreign terrorist forces to plan a terrorist attack on China's National Day (October 1st). The XUAR public security bureau then established Unit No. 307 to monitor my family members and my trading company's staff and activities. Since then, my sons have frequently been called into the office for questioning.

Last fall, I visited nine European countries and met with high-level officials to brief them on the human rights violations against my people. I have testified for six congressional hearings and have founded my own organization, the International Uyghur Human Rights and Democracy Foundation, to carry on my work. In May 2006, I was elected president of the UyghurAmerican Association.

On 29 May 2006, when another American delegation visited Urumchi, the Chinese police detained three of my eleven children: Alim (31), Ablikim (33), and Roshangul (38). My son Kahar (38) was brought from Aksu city to Urumchi two weeks later. All three of my sons were formally charged, and my daughter Roshangul and brother Mahmet were put under house arrest. 
They charged my son Kahar with tax evasion, Ablikim with subversion, and Alim with tax evasion and trying to "split the motherland." My business and property have been confiscated. In other words, the government has kept its promise of finishing my business and children.

Before I came to the government's attention, Beijing had categorized my husband, Sidiq Rouzi, as a dissident, since he was - and remains - a Uyghur intellectual who continues to criticize Chinese policies toward Xinjiang in his many writings. After spending ten years in jail, he came to the United States in 1996. Five of my younger children were able to join him two years later. After he criticized China's treatment of our people on Radio Free Asia, the government pressured me to divorce him. I refused to do so.

I love all of my children. I know they are suffering greatly in prison. I want them to be happy and live a normal life. But at the same time, I cannot stand to see the suffering of my people any longer, because they all deserve human rights, religious freedom, and democracy. Moreover, they deserve to live without fear.

Struggling for the human rights of the Uyghur people is not a crime. I will continue to raise these issues with governments, international bodies, and human rights organizations. And I know that all freedom-loving people will support me and the cause of the Uyghurs, so that they may gain their freedom and their human rights.

\section{Endnote}

1. "East Turkestan" is the term used by Uyghurs to denote the geographical region where the majority of them live. Its current political designation is the "Xinjiang Uyghur Autonomous Region" (XUAR) or just "Xinjiang." 